\title{
Changing Patterns of Family Care in Uganda: Father Absence and Patrilineal Neglect in the Face of HIV/AIDS
}

Jini Roby

Brigham Young University - Provo, jini_roby@byu.edu

Stacey Shaw

Brigham Young University - Provo, stacey_shaw@byu.edu

Elinor Wanyama Chemonges

Cole D. Hooley

Follow this and additional works at: https://scholarsarchive.byu.edu/facpub

Part of the Family, Life Course, and Society Commons

\section{Original Publication Citation}

Roby, J.L., Shaw, S.A., Chemonges, E. W., \& Hooley, C.D. (2009). Changing patterns of family care in Uganda: Father absence and patrilineal neglect in the face of HIV/AIDS. Families in Society, 90(1), 110-118.

\section{BYU ScholarsArchive Citation}

Roby, Jini; Shaw, Stacey; Chemonges, Elinor Wanyama; and Hooley, Cole D., "Changing Patterns of Family Care in Uganda: Father Absence and Patrilineal Neglect in the Face of HIV/AIDS" (2009). Faculty Publications. 2937.

https://scholarsarchive.byu.edu/facpub/2937

This Peer-Reviewed Article is brought to you for free and open access by BYU ScholarsArchive. It has been accepted for inclusion in Faculty Publications by an authorized administrator of BYU ScholarsArchive. For more information, please contact ellen_amatangelo@byu.edu. 


\title{
Changing Patterns of Family Care in Uganda: Father Absence and Patrilineal Neglect in the Face of HIV/AIDS
}

\author{
Jini L. Roby, Stacey A. Shaw, Elinor Wanyama Chemonges, \& Cole D. Hooley
}

\begin{abstract}
In this study, 162 HIV-positive mothers in Uganda were interviewed about the involvement of fathers and paternal kin, regarding current support they provide to children and as child placement options in the event of the mother's death. More than half of the children had fathers who were already deceased. Another one third had fathers who were alive but did not live with the children. Only $16 \%$ of the children were living with and being supported by their fathers. Mothers indicated a strong preference for placement with maternal kin, in contrast to traditional expectations of paternal kin care. Patterns of change in kin care throughout Uganda and sub-Saharan Africa, and implications are discussed in the context of the HIV/AIDS pandemic.
\end{abstract}

n Africa children have been viewed as traditionally belonging to their father's extended family, and orphaned children were absorbed by paternal relatives. Recently, however, this system of care appears to be disintegrating, and overburdened maternal relatives are coming forward to take the place of paternal relatives. The present study suggests this pattern of change is widespread throughout Uganda and possibly sub-Saharan Africa, exacerbated by the devastating impact of HIV/AIDS. This topic is relevant to governments, nongovernmental organizations (NGOs), and others who work in Africa and elsewhere to care for children and families impacted by AIDS, conflict, and poverty-all of which are currently producing a global crisis of orphans (UNAIDS, UNICEF, \& USAID, 2004).

The concept of Obuntu, meaning "I am what I am because of who we are" (Freeman \& Nkomo, 2006, p. 308) encapsulates the collective context in which personal identity and responsibilities are defined in Africa. The concept is foundational in Uganda's traditional patrilineal and patriarchal system, where the father's extended family, or clan, has a paramount role in the lives of the children (Ankrah, 1993; Luginaah, Elkins, Tyndale, Landry, \& Mathui, 2005; Male-Kayongo \& Onyango, 1984; McGrath, Ankrah, Schumann, \& Nkumbi, 1993; Nyambedha, Wandibba, \& Aagaard-Hansen, 2003; Seeley \& Kajura, 1993). The clan deter- mines rights, duties, inheritance, marriage, and residence; supersedes powers within individual marriages; and has the ultimate responsibility for the welfare of its members (Ankrah, 1991; Christiansen, n.d.; Gilborn, 2002; Luginaah et al., 2005; McGrath et al., 1993). As head of a unit of the clan, the father has the responsibility for the continuation of his lineage and for the well-being of his family (Ntozi \& Zirimenya, 1999; Ohuche \& Otaala, 1981). Men have the right to ownership, so they have power over the family's land, cash, inheritance, and traditional rites (Ankrah, 1991; MaleKayongo \& Onyango, 1984), and they are expected to provide for the family's general welfare (Nsamenang, 1987; Otiso, 2006).

Obuntu was also manifest in the pattern of care for children within the extended family, where children were commonly traded to form or reinforce relationships, to teach skills, or to provide economic benefits or extra labor to a relative (Aspaas, 1999; Christiansen, Yamba, \& Whyte, 2005; Isiugo-Abanihe, 1985). In the event of the death of the father, the tradition of "widow inheritance" was practiced in which the widow and orphaned children would be "inherited" by the decedent's close relative, often the "obvious" brother with the most means. In the event of the mother's death, the children stayed with the father, to be cared for by his other wife or wives (Oleke, Blystad, \& Rekdal, 2005).

But there are troubling signs fathers and the paternal extended 
family are not able to adequately meet these responsibilities, especially regarding orphaned children. In northern Uganda, the system of caring for orphans within the extended paternal network seems to be fading out, with the majority of orphans being absorbed into the maternal family (Oleke et al., 2005). Two-thirds of the grandchildren being fostered in eastern Uganda were residing with maternal kin (Whyte \& Whyte, 2004). The present study focused on south-central urban Uganda.

\section{Challenges to Fathering and Paternal Kin Care}

The apparent decline in caring for their families by fathers and paternal kin has been brought on by several developments, including economic crises in the cattle and cotton businesses, political turmoil with violent conflict, and the HIV/AIDS pandemic. Cattle, a major economic staple to tribes in Northern Uganda (Oleke et al., 2005), have been drastically reduced due to machine-gun assisted raids (Gray et al., 2003). The drop in the price for cotton and coffee, two of Uganda's major export crops, also weakened economic capacity (Oleke et al., 2005; Whyte \& Whyte, 2004). Unemployment has soared, and more women are now in the labor force than men (Uganda Bureau of Statistics, 2006), further undermining the traditional role of fathers (Silberschmidt, 2001). Violent conflicts have also taken a toll on familial roles (ElBushra, El-Karib, \& Hadjipateras, 2002; Oleke, Blystad, Moland, Rekdal, \& Heggenhougen, 2006). During the rule of Idi Amin (1971-79) followed by dictatorial regimes (1979 and 1981-86), an estimated 800,000 Ugandans were killed, creating a huge wave of orphans (Oleke et al., 2005; Tripp, 2004; Wakhweya et al., 2002). The Lord's Resistance Army (LRA) has waged a brutal conflict in northern Uganda, displacing millions from their homes (World Health Organization [WHO], 2006). The dispossession of their lands has undermined elder traditional power and community status (El-Bushra et al., 2002; Oleke et al., 2005; Summerfield, 1996). Such role displacements are difficult to renegotiate, affecting men's sense of masculinity (Silberschmidt, 2001).

But the most devastating setback in the paternal role has come from the HIV/AIDS pandemic (Deininger, Garcia, \& Subbarao, 2003; UNAIDS, UNICEF, \& USAID, 2002; 2004; UNAIDS \& WHO, 2006). Next to unsanitary blood transfusions, AIDS is most commonly transmitted in Africa through heterosexual contact (Gisselquist, Potterat, \& Vachon, 2003; Hrdy, 1987; Hunter, 1993), with men passing HIV/AIDS to women (Deniaud, 1997; Hunter, 1993), exacerbated by rapidly changing sexual norms involving multiple and casual partners (Olson \& Wilkins, 2006; Nyanzi, Nyanzi, Kalina, \& Pool, 2004; Orubuloye, Caldwell, \& Caldwell, 1993; Silberschmidt, 2001). Infected men die more quickly than their female partners, often leaving widows and children (UNAIDS, UNICEF, \& USAID, 2002). In 2005, although overall HIV infection rates were down at $6.7 \%$ (UNAIDS \& WHO, 2006), HIV/AIDS was reportedly responsible for the deaths of $65 \%$ of fathers of orphaned children in Uganda (Roby \& Shaw, 2008).

Before the AIDS pandemic, only $2 \%$ of the children in sub-Saharan Africa were orphans (Kilbride \& Kilbride, 1990)_defined as children under 18 who had lost one or both parents to any cause. Between 1990 and 2003, the number of children orphaned by AIDS jumped from less than 1 million to more than 12 million in the region (UNAIDS, UNICEF, \& USAID, 2004). In Uganda, approximately 2 million children (15\% of all children) are orphaned or otherwise vulnerable (Ministry of Gender, Labour and Social Development, 2004), and they struggle with grief, trauma, societal stigma, depression, poverty, discrimination, property grabbing, adjustment to a new caregiver, and separation from siblings (Foster, Makufa, Drew, Mashumba, \& Kambeu, 1997; Nempare \& Tang, 2003; Pillay, 2005; UNICEF, 2003; UNICEF \& UNAIDS, 1999; USAID-Zambia, 2002). Maternal orphans-children whose mothers die-often experience more severe social, emotional, and economic consequences (Giese, Meintjes, \& Proudlock, 2002).

The vast majority of orphans are still being absorbed into the extended system (Foster \& Williamson, 2000; UNAIDS, UNICEF, \& USAID, 2004), but these networks and communities are overwhelmed (Deininger et al., 2003; UNAIDS, UNICEF, \& USAID, 2004; UNAIDS \& WHO, 2006). Several have documented the changing pattern of orphan care in Africa, including the shift from paternal kin to other resources, most notably maternal kin (Nyambedha et al., 2001; 2003; Oleke et al., 2006; Whyte \& Whyte, 2004). In northern Uganda the widow inheritance system has come to an abrupt halt, and the paternal kin care system has been replaced by maternal relatives, a scheme that in the past would have been considered shameful (Oleke et al., 2005, 2006). The present study provides a comparison and complement to studies conducted in the rural north with the Langi tribe (Oleke et al., 2005, 2006) and in rural eastern Uganda with the Bunyole tribe (Whyte \& Whyte, 2004), by focusing on south-central urban Uganda, where livelihoods are not entirely dependent on the land, and most people do not live in paternal family compounds.

\section{Research Design and Methodology}

This study was conducted by a collaboration of Brigham Young University in the United States, the University of Makarere in Kampala, Uganda, and The AIDS Support Organization (TASO) located in Entebbe, in south-central urban Uganda. TASO clinics throughout Uganda provide medication, nutrition information, food support, and counseling to HIV-positive clients (The AIDS Support Organization [TASO], n.d.). TASO Entebbe has an overall client load of 14,000 individuals, although only about 2,000 receive assistance at a given time. Most clients are of the Baganda tribe-the most numerous tribe in Uganda (H. Muzoora, manager TASO Entebbe, personal communication, May 8, 2007).

\section{Research Questions}

Two research topics were explored: (1) the source of current support for children under 15 whose mothers or other primary caregivers (generically referred to as "mothers") were HIV positive and (2) the child placement preferences of the mothers in anticipation of their worsening health and eventual death.

\section{Sample and Demographical Data}

The sample was taken from women visiting TASO Entebbe's outpatient clinic during the month of June 2006, on the two open clinic days per week. These women, who were anticipating their eventual death and contemplating placement options for their children, provided a convenient sample to explore the questions regarding child placement and support patterns among parents and extended family. We had initial concerns about the generalizability of findings from this sample, as these clients were typically those whose health allowed them to travel, and who were able to 
afford the cost of transportation. Other clients were too sick to travel, couldn't afford transportation, or preferred to be served at their home by TASO's field officers (who visited them once a month with medication and counseling services) and seldom came to the clinic. However, TASO staff assured us women who came to the clinic were a good representation of the overall TASO group, as HIV symptoms and access to transportation money fluctuated, and even very sick women preferred the privacy of the clinic. Indeed, we saw some who had to be hospitalized on arrival. Open clinic days provided a convenient time to interview subjects, as many spent part of the day waiting for multiple appointments within the clinic. When clients checked in, TASO staff screened those who were qualified for the study-namely, HIV-positive female with children under the age of 15 . Nearly all women who qualified chose to participate, and on some days our trained local research assistants were unable to interview all potential participants due to lack of time.

In all, 162 women were interviewed (see Table 1). Half were ages 30-39 years, with a mean age of 35 . Some women (12\%) did not attend school at all, but the majority (57\%) had received a full or partial primary school education. The remainder (31\%) had some secondary education, including a few (2.5\%) who had received postsecondary education. The period of HIV-positive status ranged from 2 to 19 years, with a group mean of 5.8 years, and the majority (60\%) in the range of 2 to 8 years, although a surprising $23 \%$ had been positive for 9 or more years. All but two women reported they were sick with HIV/AIDS, in sharp contrast to a similar study conducted previously in Mozambique in which we

TABLE 1. Demographics of Women in Sample $(N=162)$

Age:

Half in the $30-39$ year range in age

Mean: 35 years

Range: $19-58$ years

Education:

Primary Education or less: $69 \%$

Received no schooling: $12 \%$

Secondary education: $31 \%$

Post-secondary education: $2.5 \%$

How long they've been diagnosed HIV positive:

Range: $2-19$ years

Mean: 5.8 years

2-8 years: $60 \%$

9 years or more: $23 \%$

Reported not being sick: 2 women

Lag time between diagnoses and assistance:

Mean years of being sick: 5.8 years

Mean years of receiving service: 3.7 years

Number of children:

Range: 1-7

Mean: 2.7/per woman

Caring only for biological children: $81 \%$

Biological and other related children: $14 \%$

Only caring for related children: $6 \%$

Marital status:

Married: $24 \%$

Widowed: $43 \%$

Religion:

Single (by divorce or never marrying): 34\%

Christian: $49 \%$

Catholic: $42 \%$

Moslem: 9\% found much less openness to AIDS status (Roby \& Eddleman, 2007). This openness seemed to result from TASO's encouragement of early disclosure, but there was still lag time of approximately 2 years between diagnosis and the onset of receiving assistance, with the mean of being sick at 5.8 years versus 3.7 years since beginning services at TASO.

The participants were caring for one to seven children, with a mean of 2.7 children per woman. Most (81\%) were caring only for their biological sons or daughters, and the remainder (14\%) were caring for both biological and kin children, or caring for only kin children (6\%), mostly nieces and nephews. About one fourth $(n=$ $39,24 \%)$ reported being currently married, $43 \%(n=69)$ reported being widowed, and $34 \%$ were single due to divorce or never marrying. About half of the participants $(49 \%, n=79)$ claimed Christianity as their religion, $42 \%(n=68)$ claimed Catholicism, and 9\% $(n=15)$ claimed Moslem faith.

\section{Instrument and Procedures}

A mixed design was utilized, using a 25 -item interview instrument originally developed by the first author and a colleague for a previous study in Mozambique (Roby \& Eddleman, 2007) and revised for this project. To increase validity and reliability, the instrument had been developed in collaboration with local service providers and had undergone multiple sets of pilot testing, then revised to refine to logistics and sequencing of the interview. The instrument, written in English and translated into Luganda (the language spoken by most of the participants including those who were not of the Baganda tribe), for this study, contained a combination of Likert scales and multiple-choice, ranking, and open-ended questions. It was reviewed by a local advisory board in Uganda, consisting of faculty members of the social science departments at the University of Makarere, and the management of TASO Entebbe, after which it was again pilot tested for culturespecific corrections. Human subject approval was obtained from the funding university and from TASO management. Local research assistants, all college graduates and fluent in English and Luganda, were trained to conduct the interviews. After consent was explained and signed, the interview was administered orally in the respondent's first language, and responses were recorded in English. Particular care was given to maintaining reliability of qualitative data by extensive training of the interviewers to promote neutrality and standardization of interviewing techniques. Quantitative data were entered in the Statistical Package for the Social Sciences (SPSS) program, and open-ended questions were categorized according to emerging themes and common threads.

\section{Findings and Discussion}

Because of existing multiple categories of information, each subset of findings will be presented and discussed, rather than presenting findings and discussion in separate sections.

\section{Source of Women's HIV Infection}

Not surprisingly, $80 \%(n=130)$ of the participants reported becoming infected by their husbands or long-term partners. Some $(14 \%, n=23)$ did not know how they were infected, and a small number $(5 \%, n=8)$ reported a source other than the husband or long-term partner. In Uganda men are allowed by law to have more partners than women within polygamous marriages and outside 
of marriage. As an illustration, previous to April 2007, when the Uganda Supreme Court decriminalized adultery, a married man could be convicted of adultery only if he had an affair with a married woman, whereas a married woman could be convicted for an affair with any man outside of marriage. Cohabitation is common, but common-law marriage is not recognized (Edimu, 2007), putting women at a greater disadvantage. Thus, one man can infect multiple women, resulting in a higher infection rate among women (8\%) than men (5\%) (UNAIDS \& WHO, 2006).

\section{Father Support for Children}

In total, these women were raising 435 children under 15 years of age, of whom 231 (53\%) had lost their fathers to death, and 133 (31\%) had fathers who were alive but didn't live with them; in total, $83.7 \%$ of the children did not live with their fathers. Only $16.3 \%$ ( $n$ = 71) lived with their fathers (see Figure 1).

For a closer examination of the father's role, we looked at each of the fathers the children in the household had. More than half of the women $(55 \%, n=89)$ reported there was just one father for

FIGURE 1. Children's relationship to their fathers $(N=435)$.

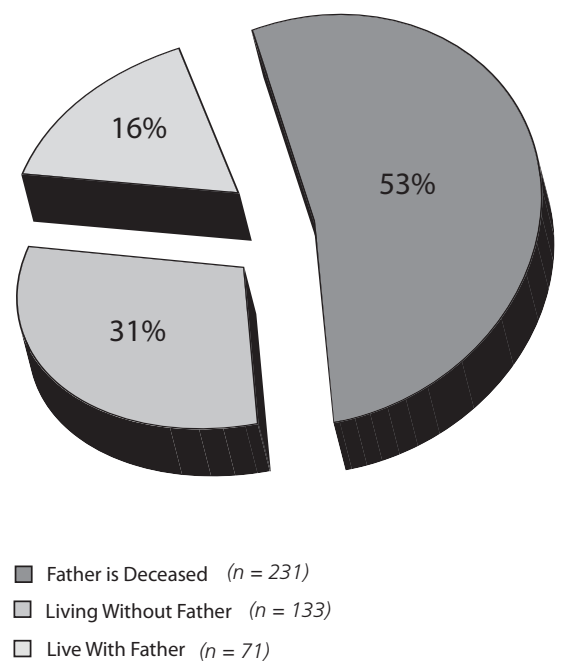

FIGURE 2. Characteristics of families with children having one or more fathers.

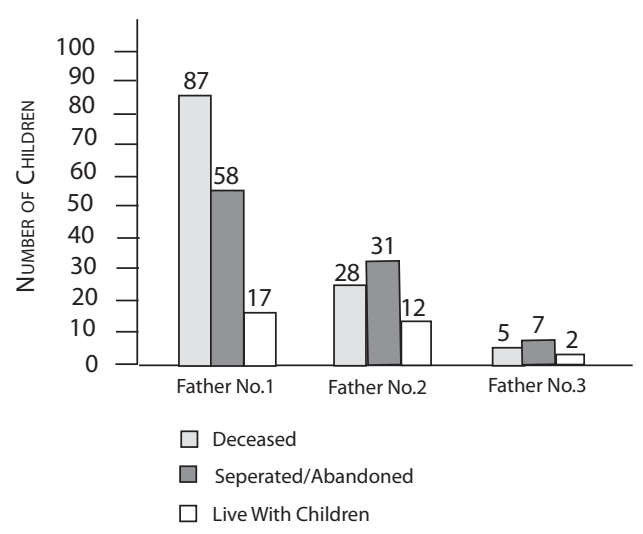

the children they were raising, more than a third $(36 \%, n=59)$ stated there were two fathers, and $8 \%(n=13)$ reported three fathers. Only one woman reported four fathers for the children she was raising and reported the fourth father had abandoned her and the children for another woman. For ease of discussion we refer to the father of the oldest child (and his or her siblings) in the woman's household as Father No. 1, and the father of the next oldest as Father No. 2, etc.

Fathers No. 1. As shown in Figure 2, there were obviously 162 Fathers No. 1 since every woman had at least one child. Of these 162 fathers, $88 \%$ did not live with the children either because they were deceased $(61 \%, n=87)$, or $(n=75)$ they had divorced/separated from the mother or abandoned the family. Only $10.5 \%$ ( $n=$ 17) of them lived with the children, and 2 (1\%) lived with them "sometimes." Deceased fathers obviously cannot provide for the children. Among living fathers, there was a dramatic difference in the level of support children received from their fathers, depending on whether they were living together or not. Fathers No. 1 who lived with the children supported their children by providing housing (100\% of fathers who lived with the children), food (94\%), medical care (88\%), school fees (71\%), and clothing (71\%); less than half were able to provide money (41\%). When Fathers No. 1 did not live with the children, their support fell dramatically, ranging from $15.4 \%$ (on food) down to $8 \%$ (for money).

Fathers No. 2. Of the 73 Fathers No. 2, 81\% $(n=59)$ did not live with the children, $16 \%(n=12)$ lived with the children, and two fathers lived with them "sometimes." Of the 59 "absent" fathers, less than half $(48 \%, n=28)$ were deceased, a smaller percentage than Fathers No. 1 possibly due to the relative recentness of their illness compared to the illnesses by Fathers No. 1. The remainder of Fathers No. $2(n=31)$ did not live with the children due to problems in the relationship, divorce, separation, and abandonment of the family. Fathers No. 2 who were alive-the 14 who lived with the children and the 17 who did not live with the childrenshowed similar patterns of support as found with Fathers No. 1, dichotomized by whether they lived with the children or not.

Fathers No. 3 \& 4. There were 14 Fathers No. 3; five had passed away, leaving nine alive. Of those, only two lived with the mother and children. We did not ask about the level of support they provided for the children. There was only one Father No. 4, and he was not living with the children because he married another woman.

Parental relationship and children's well-being. The reasons for the scant support provided by fathers was not explored, but we suspect prolonged poverty, perhaps compounded by the fathers' HIV/AIDS status. Another dimension is the difficulty in keeping the relationship together in the face of the mother's HIV infection, even when the father likely brought it home in the first place. However, we suspect the degree of formality in the relationship is strongly correlated with the support children can expect from the father and paternal family. As briefly mentioned earlier, in Uganda, there are four different types of marriages: (1) customary marriage, in which the clan gives approval and customs are followed to legitimize the marriage of one man to an unlimited number of wives; (2) Islamic marriage, which allows up to four wives per man; (3) Christian (or "church") marriage; and (4) civil marriage. The latter two each allow only one wife. Although the bride price is most commonly associated with the customary marriage, it is routinely negotiated in all types of marriages just described, establishing a relationship between the families of the bride and groom. However, usually only the marriage to the first 
wife is formalized with the bride price; hence subsequent wives and cohabiting women are not protected by the formal process. We suspect the latter groups of women-and to a large degree their children-are less valued, making it easier for husbands or partners and their families to neglect them when the mothers show signs of HIV/AIDS. This relationship between the formality of marriage and paternal child support merits further research.

\section{Fathers and Paternal Family Support in Overall Context}

In this section we discuss the support mothers receive for the children from fathers and other relatives, namely, maternal and paternal grandparents, aunts, and uncles.

Food assistance. About half the women (49\%) received food assistance, and the majority (59\%) received it primarily from TASO. Only $15 \%$ of the women listed their husbands as the primary source. Next, maternal relatives were listed $(12.5 \%)$, then paternal relatives $(1.3 \%)$.

Medical services. For medical services for the children, $43 \%$ said they were receiving assistance, with TASO as the primary source of help (58\% of those receiving assistance). One-fifth (20\%) reported the children's father paid for their medical needs, and only $4 \%$ said paternal relatives helped compared to $14.5 \%$ of maternal relatives.

Education. In the education category, $35 \%$ of the women reported they received help to pay for the children's fees at school, listing the children's father as being the top (30\%) provider of fees, followed by maternal relatives (28\%), and TASO (14\%). Paternal relatives lagged behind at 9\%. Even though Uganda began Universal Primary Education (UPE) and limited phased access to universal secondary education in February 2007, there are still fees associated with uniforms, books, and other costs.

Housing. For those who needed housing help (35\%), it was provided largely by maternal relatives (52\%) and the father of the children (38\%), with paternal relatives coming in at a distant 3\%. Apparently women who need housing assistance and are not living with the children's father are living with maternal relatives, which has implications for overall decisions about who should raise the children after the mothers' death. This pattern suggests mothers are living close to their own relatives rather than with the paternal clan, as was practiced in prior times when women married into their husband's clan and seldom had continuing contact with natal kin.

Money. Only about one fifth of the women said they received monetary assistance for the children, most frequently provided by maternal relatives (36\%) followed by fathers $(26 \%)$, with no participation by paternal relatives. This pattern has implications in the urban area where most of the respondents live, since goods and services must be purchased.

Child care. Maternal relatives provide half (50\%) of the child care needed by some (15\%) of the women, with fathers helping (38\%), suggesting most of the women are not employed outside the home and do not need child care. But when they need it, they access it mostly through their natal kin or fathers who live nearby, confirming the proximity of mothers to their natal kin and infrequent contact between the children and their paternal kin.

Transportation. Only $9 \%$ of the women reported their children received help with transportation, and when it was received, it was most often (43\%) from maternal relatives, followed by from the children's father (21\%).
In summary of this section, the women received little help from the fathers of the children even when fathers are alive, unless they were living with the children. With more than half of the fathers deceased, and another one third not living with the children and supporting them minimally, the majority of these women were clearly unable to rely on fathers or the families of the fathers to support their children at present or in the future. Their reliance on the natal family was not surprising.

\section{Fathers and Paternal Relatives as Child Placement Options}

In times past, it was said when a couple had a child in Uganda, the child belonged to them and to the clan (Kilbride \& Kilbride, 1990; Nobles, 1991; Oleke et al., 2005). However, widow inheritance and fostering within the clan are being rapidly altered (Ankrah, 1993; Hunter, 1990; Kilbride \& Kilbride, 1990; Nyambedha et al., 2003; Silberschmidt, 2001), with a form of "crisis" fostering becoming the norm (Foster, Levine, \& Williamson, 2005; Foster \& Williamson, 2000). Aside from the issue of resources, other reasons appear to be at play as well for the shift toward the maternal family. In this section we discuss mother preferences among the children's fathers, paternal grandparents, and maternal grandparents to raise their children in the event of the deaths of the mothers.

Father as a placement option. Among the women whose children's fathers were alive $(n=89), 37(42 \%)$ stated they would like the children to be with their fathers and stated it was the father's responsibility to raise the children. Several $(n=4)$ said the father could have the children only if he would provide for them. Married women were more likely to view living with the father as a very interesting option, $t(6)=22.027, p<.005$. However, only two married women said they were planning on the father being the person to care for their children in the event of their death. Forty (24.7\%) women stated they were not interested in the father caring for the children. Some of these said the father could not or did not care about the children (21.6\%) or his other wife might mistreat the children ( $n=7 ; 4.3 \%)$; three stated the father was the last option.

Mothers may be hesitant to have their children live with the fathers as growing evidence indicates living with fathers after the death or divorce of the mothers can expose children to abuse and neglect. Fathers are often detached from the day-to-day raising of the children, and research reveals these children are often mistreated by co-wives or new wives, being made to work more, kept out of school, and given less food and less desirable sleeping quarters than other children (Christiansen et al., 2005; Nyambedha et al., 2003; Oleke et al., 2006). Oleke et al.'s (2006) study in northern Uganda did not confirm the common presumption that orphans living with paternal kin were better off materially. On the contrary, orphans living with paternal kin more frequently reported poor care, heavy workloads, and greater neglect of their basic needs than orphans with maternal kin.

Maternal versus paternal grandparents as placement options. Of the 162 women in the present study, 113 responded to the option of their own parents raising their children. Half of these (51\%) worried their own parents were too sick or old to care for the children. Forty-eight percent said they would like to have children placed with them because the grandparents loved the children and would care for them. The mothers were reluctant to have the children placed with maternal grandparents not based on concerns about whether the children would be loved and cared for, but due to the advanced ages and poor health of the grandparents. 
Concerning placement with paternal grandparents, 97 women $(60 \%)$ responded to this option. Again, there was concern the grandparents were too old or sick (21\%). However, the women also stated paternal grandparents were not interested in the children $(20 \%)$ and would not take good care of them $(31 \%)$. Only $14 \%$ felt paternal grandparents could care for the children, and another $14 \%$ felt it was their responsibility. Generally women didn't respond when they felt this option was not a choice in their situation, meaning they had no contact with the paternal relatives or these relatives were not able to care for the children.

Overall, the comparisons among father, maternal relatives, and paternal relatives are telling. Despite concerns about the health of the maternal grandparents, $31 \%$ of the mothers were very interested and $26.5 \%$ were interested in this option for the children, for a total of $57.5 \%$ indicating a positive inclination. Fathers, if alive, came in next with $28 \%$ very interested and $27 \%$ interested for a total of $55 \%$ positive response. Paternal relatives lagged behind considerably at just $11 \%$ for the very interested and $26 \%$ interested for a total of $37 \%$ positively inclined (see Table 2 ).

These preferences may be the result of many of the women and children already living with or close to their maternal kin, suggesting a possible shift in patterns of locality in relation to traditional patrilineal arrangements. It could also result from more women in cohabitation or less formal marriage arrangements, combined with fathers and their families providing negligible support. Whyte and Whyte (2004) suggested it is the failure of the paternal family that has increased the pattern of dependence on maternal kin, although the latter group has always been there as a safety net. The women's HIV status may have caused a rift and perhaps shame on the paternal family, whereas maternal kin are likely to be more sympathetic, especially if it involves an intertribal marriage due to the greater likelihood the woman will not be cared for by the paternal clan beyond the death of her husband.

Another trend in kin care should be briefly noted. The property of a deceased husband traditionally reverts back to the clan, as do his widows and children. Women do not own property but are allowed to remain in the "matrimonial" home to raise children after her husband's death. However, increasingly widows are being forcibly dispossessed of their homes, in many cases with their children. Once a benevolent system of caring for women and children, it is now a system in which the father's clan finds cover under the tradition for taking the property of the father but not the responsibility of caring for his family (Bennett, Faulk, Kovina, \& Eres, 2006). This unsavory behavior, called "property grabbing," (McPherson, 2006) causes worries among parents who contemplate death

TABlE 2. Affirmative Responses by Sample to Question: "Are You Interested in the Following Family Care Options?"

\begin{tabular}{|c|c|c|c|c|c|c|}
\hline \multirow[b]{2}{*}{ Care Option $\quad(n, \%)$} & \multicolumn{2}{|c|}{ VeRY INTERESTED } & \multicolumn{2}{|c|}{ INTERESTED } & \multicolumn{2}{|c|}{ Not InTERESTED } \\
\hline & $n$ & $\%$ & $n$ & $\%$ & $n$ & $\%$ \\
\hline Father $(89,54.9 \%)$ & 25 & $28 \%$ & 24 & $27 \%$ & 40 & $45 \%$ \\
\hline $\begin{array}{l}\text { Maternal } \\
\text { grandparents }(113,69.8 \%\end{array}$ & o) 35 & $31 \%$ & 30 & $26.5 \%$ & 48 & $43 \%$ \\
\hline $\begin{array}{l}\text { Paternal } \\
\text { grandparents }(97,59.9 \%)\end{array}$ & & $11 \%$ & 25 & $26 \%$ & 61 & $63 \%$ \\
\hline
\end{tabular}

(Gilborn, Nyonyintono, Kabumbuli, \& Jagwe-Wadda, 2001; Wakhweya et al., 2002). In our present study, $88 \%(n=142)$ of the mothers did not have a written will, and of those, $81 \%(n=113)$ indicated a desire to write one. Although these mothers had few properties, they wished to designate guardians and to leave their few belongings to someone.

Finally, our findings indicate at a statistically significant rate $(t(6)=15.998, p<.05)$ younger mothers are likely to be very interested in placing their children with their own parents. This pattern is consistent with that found by Oleke and colleagues (2005) in the north, and by Whyte and Whyte (2004) in the east. Indeed, the change may be more pronounced among the urban population in this study, since people there depend less on the land and the patrilineal clan. Urbanization and conflict have created migration patterns away from the clan, diminishing kinship ties. In the crisis mode of HIV/AIDS, mothers seem to find material and emotional support from their own families, and expect the same for their children.

\section{Limitations and Implications}

Our sample of 162 women is probably about one eighth of the active female clientele served by TASO who are HIV positive and raising children under the age of 15 , so the generalizability is limited. Our sample was urban. The experience of rural women may be different. We also did not inquire about the health and employment status of the living fathers of the children, which may have shed light on their ability to support the children. We did not ask about the placement preference of the mothers with maternal aunts and uncles, but we believe these would have been popular choices gauged by the level of support received from these relatives. We do not know the generalizability of our findings to the general population of Uganda, although the overall pattern shifting from paternal to maternal extended family for support confirms more general findings by others. In addition, as with all research involving multiple languages, some nuances may have been lost despite the fluency of local assistants.

In terms of practice, fathers must be kept alive by reducing HIV/AIDS infection rates and accident-related deaths. The recent stabilization of adult HIV infection rates of 6-7\% is encouraging, but there is concern infection rates are beginning to climb again (UNAIDS \& WHO, 2006). Programs focused on HIV/AIDS, economic development, and conflict resolution must be supported (Holmgren, Kasekende, Atingi-Ego, \& Ddamulira, 1999; Invisible children, 2007; Pillay, 2003; Smith-Lindsay, 2005; Witter, 2004; Witter \& Were, 2004).

Despite Uganda's child support laws (Children Act, Sections 5 \& 6), most fathers who weren't living with their children in this study were not supporting their children. Due to lack of research on father involvement in Africa (Hewlett, 1987; Nsamenang, 1987, 2000), we do not yet know the dynamics of this widespread problem. Support provided by nonresident fathers elsewhere has been positively correlated with children's well-being (Amato \& Gilbreth, 1999) and should receive some attention as a matter of policy. This may be aided by father education and in some cases empowerment (Engle, 1997).

Father initiatives should also address active involvement in the raising of children. Studies conducted in the West on father involvement (Allen \& Daly, 2002; Cabrera, Tamis-LeMonda, Bradley, Hofferth, \& Lamb, 2000), although not conclusive or cul- 
turally presumed to fit in the Ugandan context, do suggest positive outcomes. These include decreases in child behavior problems (Amato \& Rivera, 1999), decreases in the incidence of childhood mental illness (Boyce et al., 2006), improvement in cognitive development (Yogman, Kindlon, \& Earls, 1995), stability in emotional regulation (Gottman, Katz, \& Hooven, 1997), improvement in academic achievement (Nord, Brimhall, \& West, 1997), protection from delinquent behavior, and improvement in psychological well-being (Harris, Furstenberg, \& Marmer, 1998). Fathers benefit as well from involvement with their children (Allen \& Daly, 2002; Barnett, Marshall, \& Pleck, 1992; Eggebean \& Knoester, 2001).

As mentioned earlier, father research in Africa is urgently needed for culturally appropriate programs. In the meantime, we believe it is possible and necessary to start culturally harmonious father initiatives in Uganda, to increase father's involvement both financially and emotionally, and to improve the children's relationship with paternal kin. Because paternal responsibility for children is culturally expected, we do not believe a major cultural shift is needed, but encouragement and facilitation by traditional leadership is essential.

There are two other sources to which children can look for support: government programs and community-based civil society efforts (Christiansen et al., 2005). Under the Ugandan national orphan care policy, Hope Never Runs Dry (Ministry of Gender, Labour and Social Development, 2004), the government recognizes orphans and other vulnerable children are a policy priority. However, there are not separate programs particularly targeting orphans and other vulnerable children. Rather, the government has chosen to universalize many of the basic services such as Universal Primary Education (UPE) and, starting in 2007, Universal Secondary Education (USE). We fear orphans do not receive the maximum benefit, given only those who cannot afford private school education attend public schools, creating further social stigma and stratification. The same is true of access to public hospitals and outpatient health care: The free services are often inferior. Not surprisingly, orphans are overrepresented in the child protection and juvenile delinquency arenas.

In reality, most of the orphan work is carried out by civil society, and particularly by international NGOs and faith-based organizations relying on foreign funding. Programs founded on the strengths of the community are often the most successful. For example, in our 2005 evaluation of a community-based orphan care program in and around Kampala, we learned (1) given basic material support and encouragement, economically marginalized families can develop a viable support system among themselves; and (2) children in these households felt happy and loved, and they expected to grow into adulthood in them (Shaw \& Roby, 2007).

Although these community-based family-strengthening efforts are encouraging, and indeed they form the first line of defense in combating the orphan crisis, we believe Obuntu must be expanded to include nonfamily. In cases in which children cannot be placed with kin, we believe there could be a significant number of families participating in government-sponsored foster care and possibly in-country adoptions. Finally, although beyond the scope of this article, the special problems of children living on their own (Roby \& Cochran, 2007) and children who suffer abuse at the hands of stepparents and other caregivers need further elucidation.

\section{Conclusion}

The harsh reality of the 435 children being raised by these HIVpositive women bears restating: All of their mothers are suffering from HIV/AIDS in varying degrees and moving inexorably toward death while struggling with poverty. More than half of their fathers have died, another third are alive but do not live with them, and few provide support. Their maternal relatives are valiantly trying to help, but paternal families, once the fathers are deceased or no longer living with their mothers, are not involved or cannot be relied upon. Mothers are looking mostly to place their children with maternal kin because they believe the children will be best loved there. But maternal kin households tend to be headed mostly by economically marginalized females often with compromised health. These findings mirror those by Oleke and colleagues (2005) in the north of Uganda, and Whyte and Whyte (2004) in eastern Uganda, suggesting this is a widespread pattern in Uganda. Further, based on our discussions with colleagues from other parts of Africa, a similar pattern applies across subSaharan Africa.

In terms of policy and programs, the government, which has ratified the Convention on the Rights of the Child (1989) as well as the African Charter on the Rights and Welfare of the Child (1999), must join efforts with civil society in building the capacity of families to care for their members and provide safety net assistance to households least likely to be self-sufficient, among them child-headed households. To develop more family-based care, the government should consider alternative forms of child welfare programs, among them foster care. Civil society, with community-based organization and foreign funding, tends to do the bulk of the supportive work, some of it very encouraging. But those efforts are often splintered and fall short of the overwhelming need. There is a conspicuous lack of programs to educate or strengthen the capacity of fathers for taking responsibility for their children, a call for urgent collaboration with the traditional leadership. Finally, the fundamental concepts of gender roles and rights must be brought in line to fit with contemporary life in Uganda. Concentrated effort should be focused on building the capacity of the children so they can build the future with sustainable equality, social justice, and economic equity. We believe this process will entail, to a large degree, dealing with issues of gender equity in education, marriage, property ownership and succession, employment, and child raising.

\section{References}

African Charter on the Rights and Welfare of the Child. (1999). OAU Doc. CAB/ LEG 24.9/49 (1990). Entered into force November 29, 1999. Retrieved March 19, 2008 from http://www.africa-union.org/official_documents/Treaties_\%20 Conventions_\%20Protocols/A.\%20C.\%20ON\%20THE\%20RIGHT\%20 AND\%20WELF\%20OF\%20CHILD.pdf

Allen, S. A., \& Daly, K. (2002, Fall). The effects of father involvement: A summary of the research evidence. The FII-O News, 1, 1-11.

Amato, P. R., \& Gilbreth, J. G. (1999). Nonresident fathers and children's well-being: A meta-analysis. Journal of Marriage and the Family, 61(3), 557-573.

Amato, P. R., \& Rivera, F. (1999). Paternal involvement and children's behavior problems. Journal of Marriage and the Family, 61(2), 375-384.

Ankrah, E. M. (1991). AIDS and the social side of health. Social Science \& Medicine, 32(9), 967-980.

Ankrah, E. M. (1993). The impact of HIV/AIDS on the family and other significant relationships: The African clan revisited. AIDS Care, 5(1), 5-22.

Aspaas, H. R. (1999). AIDS and the orphans in Uganda: Geographical and gender interpretations of household resources. The Social Science Journal, 36(2), 201-226. 
Barnett, R. C., Marshall, N. L., \& Pleck, J. H. (1992). Men's multiple roles and their relationship to men's psychological distress. Journal of Marriage and the Family, 54(2), 358-367.

Bennett, V., Faulk, G., Kovina, A., \& Eres, T. (2006). Inheritance in Uganda: The plight of widows and children. Georgetown Journal of Gender \& Law, 7, 451-516.

Boyce, W. T., Essex, M. J., Alkon, A., Goldsmith, H. H., Kraemer, H. C., \& Kupfer, D. J. (2006). Early father involvement moderates biobehavioral susceptibility to mental health problems in middle childhood. Journal of the American Academy of Child \& Adolescent Psychiatry, 45(12), 1510-1520.

Cabrera, N. J., Tamis-LeMonda, C. S., Bradley, R. H., Hofferth, S., \& Lamb, M. E. (2000). Fatherhood in the twenty-first century. Child Development, 71(1), 127-136.

Christiansen, C. (n.d.). Reflections on the changing patterns of care for orphans, 1-11. Retrieved March 6, 2007, from http://www.codesria.org/Links/ conferences/hiv_aids/christiansen.pdf

Christiansen, C., Yamba, B. C., \& Whyte, S. R. (2005, December). Arenas of child support: Interface of family, state and NGO provisions of social security. Presentation at New Frontiers of Social Policy Conference, Arusha, Tanzania. Retrieved June 7, 2007, from http://siteresources.worldbank.org/ INTRANETSOCIALDEVELOPMENT/Resources/revisedChristiansenetal.pdf

Convention on the Rights of the Child. (1989). UN GA Res. 44/25, November 2, 1989; Entered into force September 2, 1990. Retrieved March 19, 2008 from http://www.ohchr.org/english/law/pdf/crc.pdf

Deininger, K., Garcia, M., \& Subbarao, K. (2003). AIDS-induced orphanhood as a systemic shock: Magnitude, impact, and program interventions in Africa. World Development, 31(7), 1201-1220.

Deniaud, F. (1997). Current status of the female condom in Africa. Sante, 7(6), 405-415.

Edimu, H. (2007, May 12). The law of inheritance and will writing in Uganda. Presentation given to the joint BYU-TASO will writing team, Entebbe, Uganda. (Ms. Edimu is an attorney and the program officer for Women Lawyers Association of Uganda [FIDA]).

Eggebean, D. J., \& Knoester, C. (2001). Does fatherhood matter for men? Journal of Marriage and Family, 63(2), 381-393.

El-Bushra, J., El-Karib, A., \& Hadjipateras, A. (2002). Gender-sensitive programme design and planning in conflict-affected situations: Research report. Retrieved April 19, 2007, from http://www.acord.org.uk/Publications/G\&CResearch/ ACORD\%20Gender\%20and\%20Conflict\%20Research\%20Report.pdf

Engle, P. L. (1997). The role of men in families: Achieving gender equity and supporting children. Gender \& Development, 5(2), 31-40.

Foster, G., Levine, C., \& Williamson, J. (2005). A generation at risk: The global impact of HIV/AIDS on orphans and vulnerable children. Cambridge: Cambridge University Press.

Foster, G., \& Williamson, J. (2000). A review of current literature on the impact of HIV/AIDS in sub-Saharan Africa, AIDS 14(Suppl. 3), 275-284.

Foster, G., Makufa, C., Drew, R., Mashumba, S., \& Kambeu, S. (1997). Perceptions of children and community members concerning the circumstances of orphans in rural Zimbabwe. AIDS Care, 9(4), 391-405.

Freeman, M., \& Nkomo, N. (2006). Guardianship of orphans and vulnerable children: A survey of current and prospective South African caregivers. AIDS, 18(4), 302-310.

Giese, S., Meintjes, H., \& Proudlock, P. (2002). National Children's Forum on HIV/ AIDS: Workshop report. Children's Institute, UCT, Cape Town, South Africa. Retrieved June 7, 2007, from http://web.uct.ac.za/depts/ci/pubs/pdf/hiv/resrep/scf_final.pdf

Gilborn, L. Z. (2002). Beyond our borders: The effects of HIV infection and AIDS on children in Africa. Western Journal of Medicine, 176(1), 12-14.

Gilborn, L., Nyonyintono, R., Kabumbuli, R., \& Jagwe-Wadda, G. (2001). Making a difference for children affected by AIDS: Baseline findings from operations research in Uganda. Washington, DC: Population Council.

Gisselquist, D., Potterat, J. J., \& Vachon, F. (2003). Let it be sexual: How health care transmission of AIDS in Africa was ignored. International Journal of STD \& AIDS, 14(3), 148-161.

Gottman, J. M., Katz, L. F., \& Hooven, C. (1997). Meta-emotion: How families communicate emotionally. Mahwah, NJ: Erlbaum.

Gray, S., Sundal, M., Wiebusch, B., Little, M. A., Leslie, P. W., \& Pike I. L. (2003). Cattle raiding, cultural survival, and adaptability of East African pastoralists. Current Anthropology, 44(S5).

Harris, K. M., Furstenberg, F. F., \& Marmer, J. K. (1998). Paternal involvement with adolescents in intact families: The influence of fathers over the life course. Demography, 35(2), 201-216.

Hewlett, B. (1987). Intimate fathers: Patterns of paternal holding among Aka Pygmies. In M. Lamb (Ed.), The father's role: Cross-cultural perspectives (pp. 295-330). Hillsdale, NJ: Erlbaum.

Holmgren, T., Kasekende, L., Atingi-Ego, M., \& Ddamulira, D. (1999). Aid and reform in Uganda: Country case study. Retrieved April 19, 2007, from http:// www.worldbank.org/research/aid/africa/uganda.pdf
Hrdy, D. B. (1987). Cultural practices contributing to the transmission of human immunodeficiency virus in Africa. Reviews of Infectious Diseases, 9(6), 1109-1119.

Hunter, S. (1990). Orphans as a window on the AIDS epidemic in Sub-Saharan Africa: Initial results and implications of a study in Uganda. Social Science \& Medicine, 31(6), 681-690.

Hunter, D. J. (1993). AIDS in sub-Saharan Africa: The epidemiology of heterosexual transmission and the prospects for prevention. Epidemiology, 4(1), 63-72.

Isiugo-Abanihe, C. U. (1985). Child fostering in West Africa. Population and Development Review, 11, 53-73.

Invisible children. (2007). Retrieved April 19, 2007, from http://www. invisiblechildren.com/home.php

Kilbride, P. L., \& Kilbride, J. C. (1990). Changing family life in East Africa: Women and children at risk. University Park: Pennsylvania State University Press.

Luginaah, I., Elkins, D., Tyndale, E., Landry, T., \& Mathui, M. (2005). Challenges of a pandemic: HIV/AIDS-related problems affecting Kenyan widows. Social Science \& Medicine, 60(6), 1219-1228.

Male-Kayongo, D., \& Onyango, P. (1984). The sociology of the African family. New York: Longman.

McGrath, J., Ankrah, E. M., Schumann, D. A., \& Nkumbi, S. (1993). AIDS and the urban family: Its impact in Kampala, Uganda. AIDS Care, 5(1), 55-70.

McPherson, D. (2006). Property grabbing and Africa's orphaned generation: A legal analysis of the implications of the HIV/AIDS pandemic for inheritance by orphaned children in Uganda, Kenya, Zambia and Malawi. The HIV/AIDS Africa Project Papers. Retrieved April 19, 2007, from http://www.law.utoronto.ca/documents/ihrp/HIV_mcpherson.doc

Ministry of Gender, Labour and Social Development. (2004). National orphans and other vulnerable children policy: Hope never runs dry. Kampala: Republic of Uganda.

Nempare, P., \& Tang, D. D. (2003). The vulnerability of children and orphaned youth in Zimbabwe. In A. Singhal \& W. S. Howard (Eds.), The children of Africa confront AIDS (pp. 51-58). Athens: Ohio University Press.

Nobles, W. (1991). African philosophy: Foundations of Black psychology. In R. Jones (Ed.), Black psychology (3rd ed., pp. 47-63). Berkeley, CA: Cobb \& Henry.

Nord, C., Brimhall, D. A., \& West, J. (1997). Father's involvement in their children's schools. Washington DC: National Center for Education Statistics. Retrieved April 16, 2007, from http://eric.ed.gov/ERICDocs/data/ericdocs2/content_ storage_01/0000000b/80/26/c9/10.pdf

Nsamenang, A. (1987). A West African perspective. In M. Lamb (Ed.), The father's role: Cross-cultural perspectives (pp. 273-293). Hillsdale, NJ: Erlbaum.

Nsamenang, A. (2000). Fathers, families, \& child well-being: A review of the literature. Philadelphia: National Center on Fathers and Families. Retrieved April 16, 2007, from http://www.ncoff.gse.upenn.edu/wrkppr/BamePaper.pdf

Ntozi, J., \& Zirimenya, S. (1999). Changes in household composition and family structure during the AIDS epidemic in Uganda. In I. O. Orubuloye, J. Caldwell, \& J. P. Ntzoi (Eds.), The continuing African HIV/AIDS epidemic: Responses and coping strategies (pp. 193-209). Canberra, Australia: Health Transition Centre. Retrieved March 9, 2007, from http://htc.anu.edu.au/pdfs/ ContinuingHIV/Ntozi_Ziri.pdf

Nyambedha, E. O., Wandibba, S., \& Aagaard-Hansen, J. (2001). Policy implications of the inadequate support systems for orphans and western Kenya. Health Policy, 58, 83-96.

Nyambedha, E. O., Wandibba, S., \& Aagaard-Hansen, J. (2003). Changing patterns of orphan care due to the HIV epidemic in western Kenya. Social Science \& Medicine, 57(2), 301-311.

Nyanzi, S., Nyanzi, B., Kalina, B., \& Pool, B. (2004). Mobility, sexual networks and exchange among bodabodamen in southwest Uganda. Culture, Health \& Sexuality, 6(3), 239-254.

Ohuche, R. O., \& Otaala, B. (Eds.) (1981). The African child and his environment. New York: Pergamon Press.

Oleke, C., Blystad, A., Moland, K., Rekdal, O., \& Heggenhougen, K. (2006). The varying vulnerability of African orphans: The case of the Langi, northern Uganda. Childhood 13(2), 267-284.

Oleke, C., Blystad, A., \& Rekdal, O. B. (2005). When the obvious brother is not there: Political and cultural contexts of the orphan challenge in northern Uganda. Social Science \& Medicine, 61(12), 2628-2638.

Olson, T. D., \& Wilkins, R. G. (2006). The family, youth, and AIDS. In D. E. Morisky, W. J. Jacob, Y. K. Nsubuga, \& S. J. Hite (Eds.), Overcoming AIDS: Lessons learned from Uganda (pp. 225-246). Greenwich, CO: Information Age.

Orubuloye, I. O., Caldwell, P., \& Caldwell, J. C. (1993). The role of high-risk occupations in the spread of AIDS: Truck drivers and itinerant market women in Nigeria. International Family Planning Perspectives, 19(2), 43-48.

Otiso, K. M. (2006). Culture and customs of Uganda. Westport, CT: Greenwood.

Pillay, Y. (2003). Storytelling as a psychological intervention for AIDS orphans in Africa. In A. Singhal, \& W. S. Howard (Eds.), The children of Africa confront AIDS (pp. 105-118). Athens: Ohio University Press. 
Pillay, Y. (2005). Peer victimization of African children orphaned by AIDS: The efficacy of the memory book [Special issue]. Journal of Social Sciences, (8), 21-27.

Roby, J. \& Cochran, G. (2007). Child-headed households in Mozambique: Toward needs-based policy and practice. Social Development Issues, 29(3), 19-32.

Roby, J., \& Eddleman, N. (2007). When she is gone: Child placement options and plans of Mozambican mothers with terminal illnesses. Families in Society: The Journal of Contemporary Social Services, 88 (2), 292-301.

Roby, J., \& Shaw, S. (2008). Evaluation of a community-based orphan care program in Uganda. Families in Society: The Journal of Contemporary Social Services, 89(1), 119-128.

Seeley, J., \& Kajura, E. (1993). The extended family and support for people with AIDS in a rural population in south west Uganda: A safety net with holes? AIDS Care, 5(1), 117-122.

Silberschmidt, M. (2001). Disempowerment of men in rural and urban East Africa: Implications for male identity and sexual behavior. World Development, 29(4), 657-671.

Shaw, S., \& Roby, J. (2007). Child welfare perspectives of caregivers raising orphans and vulnerable children in Uganda. Journal of Social Development in Africa, 22(2), 9-34.

Smith-Lindsay, C. (2005). The memory book and its close relations. Retrieved March 19, 2007, from http://www.medicusmundi.ch/mms/services/bulletin/ bulletin200503/kap03/06smith.html

Summerfield, D. (1996). The impact of war and atrocity on civilian populations: Basic principles for NGO interventions and a critique of psychosocial trauma projects. London: Overseas Development Institute. Retrieved April 19, 2007, from http://www.torturecare.org.uk/UserFiles/File/publications/Summ_4.rtf

The AIDS Support Organization (TASO) (n.d.). Retrieved May 10, 2007, at http:// www.tasouganda.org/training_cent.php

Tripp, A. M. (2004). The changing face of authoritarianism in Africa: The case of Uganda. Africa Today, 50(3), 3-26.

Uganda Bureau of Statistics. (2006). Labour statistics. Retrieved April 20, 2007, from http://www.ubos.org/stlabour.html

UNAIDS, UNICEF, \& USAID. (2002). Children on the brink 2002: A joint report on orphans estimates and program strategies. Washington, DC: USAID.

UNAIDS, UNICEF, \& USAID. (2004). Children on the brink 2004: A joint report of new orphan estimates and a framework for action. New York: Population, Health, and Nutrition Information Project.

UNAIDS \& World Health Organization (WHO). (2006). AIDS epidemic update. Zurich, Switzerland: UNAIDS.

UNICEF. (2003). Africa's orphaned generations. New York: Author.
UNICEF \& UNAIDS. (1999). Children orphaned by AIDS: Front-line responses from eastern and southern Africa. New York: UNICEF.

USAID-Zambia. (2002). Results of the orphans and vulnerable children head of household baseline survey in four districts in Zambia. Retrieved March 16, 2007, from http://www.fhi.org/NR/rdonlyres/

Wakhweya, A., Kateregga, C., Konde-Lule, J., Mukyala, R., Sabin, L., Williams, M., et al. (2002). Situational analysis of orphans in Uganda. Orphans and their households: Caring for the future-today. Kampala: Government of Uganda Ministry of Gender, Labour, and Social Development and Uganda AIDS Commission.

Whyte, S., \& Whyte, M. (2004). Children's children: Time and relatedness in eastern Uganda. Africa, 74(1), 76-94.

Witter, S. (2004). Breaking the silence: Memory books and succession planning the experience of NACWOLA and Save the Children UK in Uganda. London: Save the Children. Retrieved March 16, 2007, from http://www.savethechildren.org. uk/scuk_cache/scuk/ cache/cmsattach/1838_Memory_Books.pdf

Witter, S., \& Were, B. (2004). Breaking the silence: Using memory books as a counseling and succession-planning tool with AIDS-affected households in Uganda. African Journal of AIDS Research, 3(2), 139-143.

World Health Organization (WHO). (2006). Uganda WHO strategy paper for 2006. Retrieved April 19, 2007, from http://www.who.int/hac/crises/uga/Uganda_ StrategyPaper_February06_draft.pdf

Yogman, M. W., Kindlon, D., \& Earls, F. (1995). Father involvement and cognitive/ behavioral outcomes of preterm infants. Journal of American Academy of Child \& Adolescent Psychiatry, 34(1), 58-66.

Jini L. Roby, JD, MSW, MS, is associate professor, School of Social Work, Brigham Young University. Stacey A. Shaw, MSW, CSW, is clinical coordinator, International Rescue Committee, Salt Lake City, UT. Elinor Wanyama Chemonges, MSC, DipSW, is national coordinator, Paralegal Advisory Services, Foundation for Human Rights Initiative. Cole D. Hooley, is research fellow, School of Social Work, Brigham Young University. Correspondence regarding this article should be sent to the first author at jiniroby@byu.edu or School of Social Work, 2166 JFSB, Brigham Young University, Provo, UT 84602.

Manuscript received: June 20, 2007

Revised: November 16, 2007

Accepted: November 17, 2007 